\title{
Report
}

\section{Yearly events report}

\author{
A.G. Nerkar ${ }^{1,2,3, *}$ \\ ${ }^{1}$ Dept. of Medicinal Chemistry and Pharmacology, Parul Institute of Pharmacy \& Research, Parul University, Vadodara, \\ Gujarat, India \\ ${ }^{2}$ Founder and Director, Ateos Foundation of Science Education and Research, Pune, Maharashtra, India \\ ${ }^{3}$ Founder and Director, Carolene Therapeutics, Pvt. Ltd, Aurangabad, Maharashtra, India
}

\section{A R T I C L E I N F O}

\section{Article history:}

Received 08-09-2021

Accepted 20-09-2021

Available online 16-11-2021
This is an Open Access (OA) journal, and articles are distributed under the terms of the Creative Commons Attribution-NonCommercial-ShareAlike 4.0 License, which allows others to remix, tweak, and build upon the work non-commercially, as long as appropriate credit is given and the new creations are licensed under the identical terms.

For reprints contact: reprint@ipinnovative.com
Ateos Foundation of Science

Education and Research

\section{YEARLY EVENTS REPORT}

2021- 2022

(Jan 2021- Dec 2021)

\section{Preface}

Ateos Foundation of Science Education and Research (AFSER) is a Non Profit Organization. AFSER has all the statutory and mandatory approvals from Govt. of India. AFSER has objectives to Promote Science, research and development activity for skilled Indian youths in fields of Pharmacy, Engineering, Science, Medical, Dental

\footnotetext{
* Corresponding author.

E-mail address: dragnerkar@gmail.com (A. G. Nerkar).
}

Sciences and large Sciences streams of all specializations. It aims to fill the gap between educational needs and actual practical approach of the students of science streams of all kinds, towards the society. Also promote/conduct various online and offline programs and promoting the Science for the benefit and development of Indian Youths. These activities are being conducted under the eminent visionary leadership of Dr. Amit Nerkar., who is Doctorate in Pharmaceutical Sciences and has vast experience in teaching and research. His profile can be surfed throughout the internet. Further through his magnanimous leadership, he strives to develop quality network of highly qualified eminent professionals from Pharmacy, Science and Technology, Medical and Paramedical Sciences. We look forward for your cooperation to join our noble cause of skilled India moment and medical and health social work.

\section{Background}

Ateos Foundation Of Science Education And Research's Corporate Identification Number is (CIN) U85300PN2020NPL191407 and its registration number is 191407, incorporated on 20 June 2020. AFSER is Non Profit Organization (NPO) and supports the cause of the skilled India Movement and strives and thrives to skill the Indian youth for nation building. AFSER has conducted several programmes by quality education and skilling the 
youth through its direct and indirect methods.

The direct interaction methods include:

1. Journal: Current trends in Pharmacy and Pharmaceutical Chemistry wherein a plethora of research has been published from the eminent personalities in the field of Pharmacy. A special Thematic issue on the Virology and Human Health and another Thematic Issue on Formulation of Herbal Products had also been published during the Covid-19 lockdown phase. Thus serving the Scientific communities.

2. Online and Offline Courses: These courses have been shared and online courses of short duration i.e. of 3-6 months are the main eye catchers as the Individuals earns a certificate with logo of AFSER, India.The courses shall be beneficial for the students of Pharmacy, Science and Technology, Medical and Paramedical Sciences to upgrade their skill in the given area and for the future prospects of solving their problem of employment. The AFSER certificate holder will be always outstanding and will be worth and employable.

3. Direct Medical and Health Social Work Services: This is a unique programme of AFSER and being carried out with sister entity Carolene Therapeutics Pvt. Ltd. During the Covid-19 lockdown period AFSER has served the society by making Sanitizers and masks freely available and several other pharmaceutical services.

The indirect development initiatives of AFSER include:

\section{Fellow Membership Awards}

1. As mentioned earlier AFSER is not for profit organization and generates its own funds through these direct and indirect programs. Further it spends the same for the new or the existing programs. AFSER has the main motto of nation building and to serve the society and nation through its medical health social work and education programs.

2. AFSER believes that a skilled nation makes more chances of making economically and educationally sound citizens for national development leading to a prosperous nation.

3. We humbly look forward to your generous monetary donations to our foundation so that we serve our nation better in every possible effort we can.

\section{Journals}

Current Trends in Pharmacy and Pharmaceutical Chemistry is the official Journal of Ateos Foundation of Science Education and Research, hosted and Managed by IP
Innovative Publications Pvt.Ltd. under the editorship of Dr Amit G.Nerkar.

\section{E-ISSN: 2582-5062}

The aim of the journal is to peer review and publish recent advances as well as trivial approaches in Pharmacy and especially pharmaceutical chemistry research. The journal strives for the quality publications and will accept high-quality research. The peer review system shall be scrutinizing the facts of the publications with due care of scientific temper of the research findings of the author.

Current Trends in Pharmacy and Pharmaceutical Chemistry is peer-reviewed Journal invites manuscripts of review and research articles in areas mentioned below:

All disciplines of pharmacy, pharmaceutical sciences and all disciplines of pharmaceutical chemistry

1. Pharmaceutical Chemistry

2. Pharmaceutical Analysis

3. Medicinal Chemistry

4. Natural Product Chemistry

5. Drug Design

6. Pharmaceutical Organic Chemistry

7. Drug Discovery

Click on to www.ctppc.org to visit the Journal

\section{Objectives}

"To Promote Science, research and development activity for skilled Indian youths in fields of Pharmacy, Engineering, Science, Medical, Dental Sciences and large Sciences streams of all specializations. It aims to fill the gap between educational needs and actual practical approach of the students of science streams of all kinds, towards the society. Also promote/conduct various online and offline programs and promoting the Science for the benefit and development of Indian youth from Science background and to do all incidental acts and things necessary for the attainment of objects under these presents. Also carry on below activities:

1. Contributing to sustenance, planning and coordination of science and technology.

2. Concerning itself with the improvement and modernization of science education in schools, colleges, universities and technical institutions of the country.

3. Undertaking, encouraging and promoting studies of problems concerning:

1.The exploration and exploitation of natural resources of the county

2.Balanced agricultural and industrial development, consistent with the environmental and socio-economic objectives of the County.

4. Concerning itself with the role of science and technology in the service of the rural community. 
5. Endeavouring to create informed public opinion on matters of science and technology relevant to the County.

- Cooperate with the Government, and make available to the Government, the results of its studies and expert investigations, as well as undertake special studies on behalf of the Government when called upon to do so.

- Cooperate with industries in the County in attempts to solve technological problems facing them.

- Promote the development of appropriate technologies in relation to the social, economic and geographic conditions.

- To promote research projects and studies on scientific and technological problems of special relevance.

- Cooperate with other learned bodies in and outside the County for the promotion, utilization and popularization of science.

- Promote and maintain liaison between science, humanities and letters.

- Undertake publications of research papers, reports, journals, monographs and books and other audio-visual aids in various fields of science and technologies.

- Organize meetings, seminars and conferences for the benefit of Science.

- Secure and manage funds and endowments for the promotion of science and technology.

- Undertake and execute all other acts which will assist and promote the usefulness, aims and purposes of the Company on non profit basis.

\section{Events Report}

\section{Jan-Feb 2021}

\section{Year Commencement Date: 27-01-2021}

1. Convocation of First Batch of Online Certification Course in Biopharmaceutics

2. Sending Certificate to the Participants of Online Certification Course in Biopharmaceutics

3. 15 Days in online Workshop on Facing Interviews in Pharmaceutical Fields from 27th Jan 2021 till 10th Feb 2021.In association with Wisdommine LLP.,Pune

4. 2-Days Online Workshop on Basics of Pharmacognosy , 12-13th Feb 2021., Speaker: Prof. Dr. G. S. Chakraborthy, Professor and Director, Parul University's Institute of Pharmacy and Research, Vadodra, Gujarat., India

5. 3-Days Online Workshop on Basics of Pharmacology, 17-19th Feb 2021., Speaker: Prof. Dr. S. D. Ambavade, Professor and Dean, School of Pharmaceutical Sciences, Sanjay Ghodawat University., Kolhapur M.S., India

\section{March-April 2021}

1. Online Certification Course on Biopharmaceutics, from 15 ${ }^{\text {th }}$ March 2021 till $15^{\text {th }}$ June 2021- Second Batch

2. 3-Days Online Workshop on Basics of QA and QC, 12 $2^{\text {th }}-14^{\text {th }}$ March 2021.,Speaker: Prof. Dr. S. S. Chalikwar and Dr. V. P. Sonar, Department of Quality Assurance, SES's R.C.Patel Institute of Pharmaceutical Ed. And Res, Shirpur, Dist-Dhule, M.S., India

3. 3-Days Online Workshop on Basics of Medicinal Chemistry, 12 $2^{\text {th }}-14^{\text {th }}$ April 2021., Speaker: Prof. Dr. Amit G. Nerkar., Founder and Director, Ateos Foundation of Science Education and Research, Pune, M.S., India

4. 3-Days Online Workshop on Basics of Solid Oral Dosage Forms, 15 th $-17^{\text {th }}$ April 2021 First Batch., Speaker: Assoc. Prof. Dr. Nilesh B.Kulkarni., Department of Pharmaceutics, SES's R.C.Patel Institute of Pharmaceutical Ed. And Res, Shirpur, Dist-Dhule, M.S., India.

\section{May-June 2021}

1) One Day Webinar by Dr. Disha Parikh on on 16th May 2021 at 6.30 pm, "Webinar on Stress Free Studying during Pandemic-Coping with the new normals in education by Dr. Disha Parikh, MD (Psychiatry), The Beautiful Minds Clinic Pune, M.S., India.

\section{July-Aug 2021: $15^{\text {th }}$ July to $15^{\text {th }}$ Aug Yearly Vacation}

\section{August-Sept 2021}

- Ateos Foundation of Science Education and Research sponsored a webinar of ACTREC, Khargar, Navi Mumbai, M.S., India , on Humanized Mice \& Applications in Healthcare Research" on $19^{\text {th }}$ August, 2021 from $5.30 \mathrm{pm}$ to $7.30 \mathrm{pm}$ on youtube live platform

\section{Sept-Oct 2021}

1. Short Term Course in Family Medicine of Sensory Disorders for Pharmacists and Allied Health Sciences on Udemy.,

visit the link : https://www.udemy.com/course/short-te rm-course-in-family-medicine/

2. Online Certification in Basics of Medicinal Chemistry uploaded on Udemy.

Visit the Link : https://www.udemy.com/course/basics -of-medicinal-chemistry/

3. Published the Vol 3, Issue 3, of Journal Current Trends in Pharmacy and Pharmaceutical Chemistry on IP Innovative Publications Publishing Platform.

Visit the link : ctppc.org 
4. Online Certificate Course in Pharmaceutical Quality Assurance uploaded and published on Udemy visit the link: https://www.udemy.com/course/certifica te-course-in-pharmaceutical-quality-assurance/

\section{Nov- Dec 2021}

1. Online Certification Course on Biopharmaceutics, Uploaded on Udemy.

Visit The link : https://www.udemy.com/course/certifi cation-in-biopharmaceutics-d/

2. Published the Vol 3, Issue 4 of Journal Current Trends in Pharmacy and Pharmaceutical Chemistry on IP Innovative Publications Publishing Platform. Visit the link : ctppc.org

3. Online Certification in Basics of Biochemistry on Udemy (upcoming)

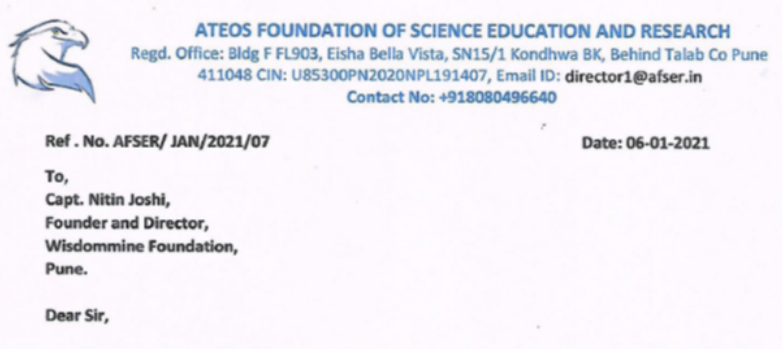

Ateos Foundation of Science Education and Research has an objective to train the youth and to develop skilled and qualified individuals. Further to state that our objective is to serve Science, Medicine, Pharmacy, Dental, paramedical and Engineering sciences for their skil development which shall indirectly serve wellbeing of our society and by and large our nation.

With Reference to above mentioned subject, I am pleased to invite you to collaborate for our Joint Venture in online Lecture series "Facing Interviews in Pharmaceutical Fields Lecture series", To be conducted yearly if possible. Kindly let me know your terms and conditions over the email/ on your letter head to process further. As per earlier telephonic discussion and mutual consent the online Forms are released over the registration and the commencement for the said course shall be from $27^{\mathrm{th}}$ Jan 2021 till $10^{\mathrm{mb}} \mathrm{Feb} 2021$. (Tentative dates).

Hoping for positively reply.
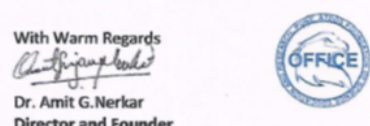

Dr. Amit G.Nerkar
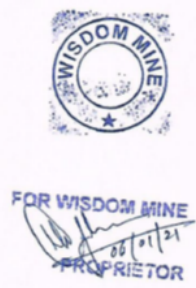

1. Convocation of First Batch of Online Certification Course in Biopharmaceutics Sept 2020- June 2021

2. 15 Days in online Workshop on Facing Interviews in Pharmaceutical Fields from $27^{\text {th }}$ Jan 2021 till $10^{\text {th }}$ Feb 2021.In association with Wisdommine LLP., PuneFirst Batch

\section{Details of the Programs Conducted}

\section{Jan-Feb 2021}

MoU was Signed with Capt. Nitin Joshi, Wisdommine LLP

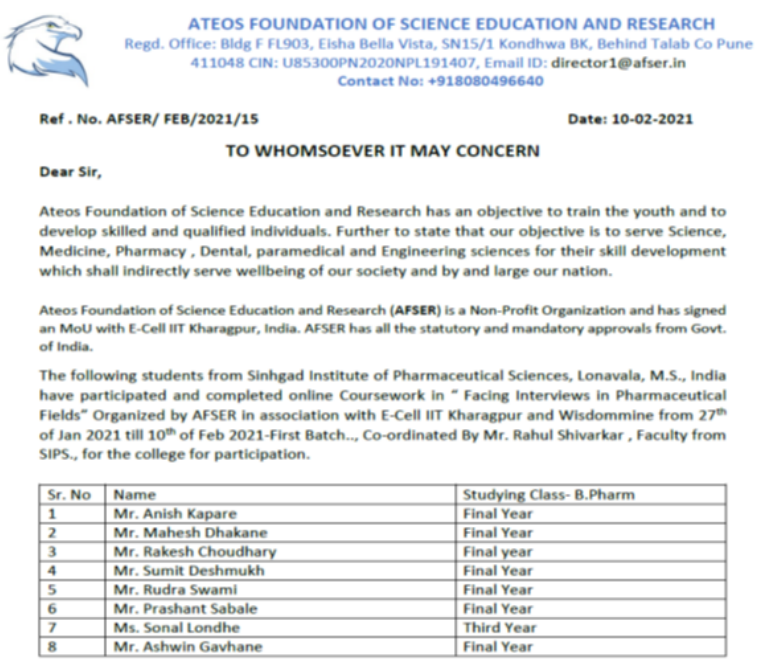

We heart-fully thank and appreciate the participation of these students and wish them all the best for futurell!

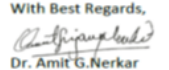

Dr. Amit G.Nerkar

Director and Found of

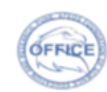

1. 2-Days Online Workshop on Basics of Pharmacognosy , 12-13th Feb 2021.,Speaker: Prof. Dr. G. S. Chakraborthy, Professor and Director, Parul University's Institute of Pharmacy and Research, Vadodra, Gujarat., India

2. 3-Days Online Workshop on Basics of Pharmacology, 17-19th Feb 2021.,Speaker: Prof. Dr. S. D. Ambavade, Professor and Dean, School of Pharmaceutical Sciences, Sanjay Ghodawat University., Kolhapur M.S., India.

3. One Day Webinar by Dr. Disha Parikh on on 16th May 2021 at 6.30 pm, "Webinar on Stress Free Studying during Pandemic-Coping with the new normals in education by Dr. Disha Parikh, MD (Psychiatry), The Beautiful Minds Clinic Pune, M.S., India.

4. Ateos Foundation of Science Education and Research sponsored a webinar of ACTREC, Khargar, Navi Mumbai, M.S., India , on Humanized Mice \& Applications in Healthcare Research" on $19^{\text {th }}$ August, 2021 from $5.30 \mathrm{pm}$ to $7.30 \mathrm{pm}$ on youtube live platform

With Gratitude and Sincere Thanks to Central Government of India, For Making our Dream turn into Reality!!! 
Schedule for the program is as follows

\begin{tabular}{|c|c|c|c|c|}
\hline Sr. No & Date & Time & Topic & Resource Person \\
\hline 1 & 27 Jan 2021 & $8.30 \mathrm{pm}-9.15 \mathrm{pm}$ & CV Writing & Captain Nitin Joshi \\
\hline 2 & 28 Jan 2021 & $8: 30 \mathrm{pm}$ & Top Interview Questions & Captain Nitin Joshi \\
\hline 3 & 29 Jan 2021 & $8.30 \mathrm{pm}$ & $\begin{array}{l}\text { CV Template ( } 1 \text { page and Brief } \\
\text { Resume) }\end{array}$ & Captain Nitin Joshi \\
\hline 4 & 30 Jan 2021 & $8.30 \mathrm{pm}$ & Communication Skill and mannerism & Captain Nitin Joshi \\
\hline 5 & 31 Jan 2021 & $8.30 \mathrm{pm}$ & Writing Cover Letters and Applications & Captain Nitin Joshi \\
\hline 6 & 1Feb 2021 & $8.30 \mathrm{pm}$ & Judging Domains in the interview & Captain Nitin Joshi \\
\hline 7 & 2 Feb 2021 & $6.00 \mathrm{pm}$ & Regulatory Interviews & Mr. Amol Kakade \\
\hline 8 & 3 Feb 2021 & $6.00 \mathrm{pm}$ & Clinical Trials Interviews & $\begin{array}{l}\text { Mr. Tigi David \& Mr. } \\
\text { Raju Jawale }\end{array}$ \\
\hline 9 & 4 Feb 2021 & $6.00 \mathrm{pm}$ & Pharmacovigilance Interviews & Mr. Swapnil Lavande \\
\hline 10 & 5 Feb 2021 & $6.00 \mathrm{pm}$ & Marketing Interviews & Mr. Rakesh Shedole \\
\hline 11 & 6 Feb 2021 & $6.00 \mathrm{pm}$ & QA and QC interviews & Mr. Vishesh Mohod \\
\hline 12 & 7 Feb 2021 & $6.00 \mathrm{pm}$ & Formulation $\mathrm{R}$ and $\mathrm{D}$ Interviews & Mr. Amit Bukkawar \\
\hline 13 & 8 Feb 2021 & $6.00 \mathrm{pm}$ & $\begin{array}{l}\text { Editorial Panel Interviews/ API Industry } \\
\text { Interviews }\end{array}$ & $\begin{array}{l}\text { Mr. Deepak Pawar / } \\
\text { Mr. Vivek Joshi }\end{array}$ \\
\hline 14 & 9 Feb 2021 & $6.00 \mathrm{pm}$ & $\begin{array}{l}\text { Production and Analytical R and D } \\
\text { Interviews }\end{array}$ & $\begin{array}{l}\text { Mr. Rahul } \\
\text { Govindwar and Mr. } \\
\text { Shivanand Mante }\end{array}$ \\
\hline 15 & 10 Feb 2021 & $6.00 \mathrm{pm}$ & Academic Interviews and Closing Day & Dr Amit Nerkar \\
\hline
\end{tabular}

Speakers

Regulatory Interviews

Clinical Trials Interviews

Pharmacovigilance Interviews

Marketing Interviews

QA and QC interviews

Formulation R and D Interviews

Editorial Panel Interviews/ API Industry Interviews

Production and Analytical R and D Interviews
Mr. Amol Kakade Deputy Manager, DRA, Alkem Laboratories

1) Mr. Tigi David Senior Clinical Trial Manager, 2) Mr. Raju Jawale Senior Centralized Clinical Trial Manager ICON PLC

Mr. Swapnil Lavande Sr. Process Associate TCS

Mr. Rakesh Shedole Therapy Business Manager, Abott Laboratories Mr. Vishesh Mohod Senior Centralized Complicance Manager, Centaur Laboratories

Mr. Amit Bukkawar AGM (Formulation R and D) MSN Laboratories Pvt. Ltd.

1) Mr. Deepak Pawar Editorial Advisor, Springer Nature.

2) Mr. Vivek Joshi Independent Consultant

Mr. Rahul Govindwar Senior Scientist (Analytical R and D) Wockhardt, Aurangabad Mr. Shivanand Mante $2^{\text {nd }}$ Director Carolene Therapeuitcs Pvt. Ltd

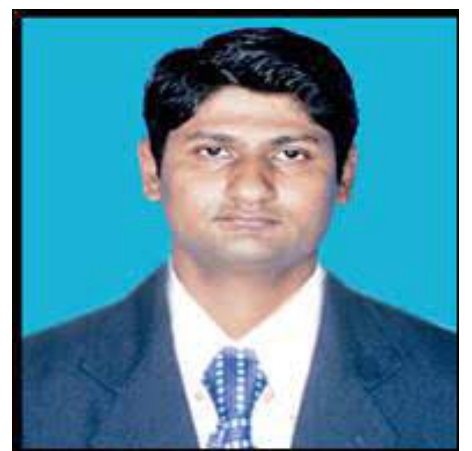

Dr. Amit G.Nerkar,

Founder and Director,

AFSER.

\section{Biodata of the Founder and Director}

Dr. Amit G. Nerkar obtained his Bachelors in Pharmacy from Vidya Bharati College of Pharmacy, Amravati, M.S., India., Masters in Pharmacy in Pharmaceutical (Medicinal) Chemistry from College of Pharmaceutical Sciences (Govt. Aided), Odisha affiliated to Biju Patnaik University of Technology, Odisha, India. He obtained his Doctorate (Ph.D) in Pharmaceutical Sciences from School of Pharmacy and Technology Management, NMIMS University, Mumbai. During his PhD he worked as Senior Research Fellow for Indian Council of Medical Research, Ministry of Health and Family Welfare, New Delhi. He has 47 presentations in Conferences of National and International Levels and 56 Publications in SCI indexed journals with SCI Mago Impact Factor. He is also member of Editorial Board for many SCI indexed Journals. Dr. 
Amit Nerkar is well proficient with Organic Chemistry and Medicinal Chemistry, Clinical Pharmacology and some of his major research area include Computer Aided Drug Design, In silico Virtual Screenings, 2-D \& 3-D QSAR, Synthesis of Novel and Bioactive Molecules and Pharmacological Screenings. He is currently working as Professor in Pharmaceutical Chemistry at Parul Institute of Pharmacy and Research, Vadodara, Gujarat, India. He has funding grants from Central Funding agencies of India, worth INR 54,00,000. He has several grants for seminars and conferences as convener as well. He also has passed his certification in Clinical Pharmacology from Harvard Medical School, USA and National Institutes of Health, Department of Health and Human Services, Office of Clinical Research, USA. He involved in philanthropic education in through his Non-Profit Organization Ateos Foundation of Science Education and Research, Pune, M.S., India and philanthropic pharmaceutical and medical aid services through his self-owned enterprise Carolene Therapeutics Pvt. Ltd.

\section{Author biography}

A.G. Nerkar, Professor

Cite this article: Nerkar AG. Yearly events report. Curr Trends Pharm Pharm Chem 2021;3(4):68-73. 